\title{
Key environmental determinants of global and regional richness and endemism patterns for a wild bee subfamily
}

\author{
Nadia Bystriakova ${ }^{1}$ (D) Terry Griswold ${ }^{2} \cdot$ John S. Ascher ${ }^{3} \cdot$ \\ Michael Kuhlmann ${ }^{1,4}$
}

Received: 22 January 2017/Revised: 25 August 2017/Accepted: 2 September 2017/

Published online: 16 September 2017

(C) The Author(s) 2017. This article is an open access publication

\begin{abstract}
Reports of world-wide decline of pollinators, and of bees in particular, raise increasing concerns about maintenance of pollination interactions. While local factors of bee decline are relatively well known and potential mitigation strategies at the landscape scale have been outlined, the regional and continental-scale threats to bee diversity have only been marginally explored. Here we document large-scale spatial patterns for a representative bee subfamily, the determinants of its species richness, and assess major threats to these pollinators. Using a comprehensive global dataset of Colletinae (genera Colletes, also called "polyester" or "cellophane" bees for their underground nests lined with a polyester secretion, and Mourecotelles), a species-rich subfamily whose organismal and physiological ecology is representative of many bees, we measured species richness and endemism on global to continental scales. We explored the relationships between bee species richness and potential environmental stress factors grouped into three categories: contemporary climate, habitat heterogeneity, and anthropogenic pressure. Bees of the subfamily Colletinae demonstrate the reversed latitudinal gradient in species richness and endemism suggested for bees; the highest species richness of Colletinae was found between $30^{\circ}$ and $50^{\circ}$ latitude in both the northern and southern hemispheres. Centres of endemism largely overlapped with those of species richness. The importance of the Greater Cape Floristic Region, previously identified as a centre of richness and endemism of bees,
\end{abstract}

Communicated by Raphael K. Didham.

Electronic supplementary material The online version of this article (doi:10.1007/s10531-017-1432-7) contains supplementary material, which is available to authorized users.

Nadia Bystriakova

n.bystriakova@nhm.ac.uk

1 Department of Life Sciences, Natural History Museum, London, UK

2 USDA ARS Pollinating Insects Research Unit, Utah State University, Logan, UT, USA

3 Department of Biological Sciences, National University of Singapore, Singapore, Singapore

4 Zoological Museum, University of Kiel, Kiel, Germany 
was confirmed for Colletinae. On the global scale, present-day climate was a significant predictor of species richness as was flowering plant diversity represented by vascular plant species richness and centres of plant diversity. Our main conclusion is that climate change constitutes a potential threat to bee diversity, as does declining diversity of vascular plants. However, a significant overlap between centres of bee richness and plant diversity might increase chances for developing conservation strategies.

Keywords Species richness - Weighted endemism · Latitudinal diversity gradient $\cdot$ Macroecological analysis $\cdot$ Invertebrates $\cdot$ Colletidae $\cdot$ Cape Region

\section{Introduction}

Bees are the most important animal group, pollinating the nearly $90 \%$ of all flowering plants that require pollination (Ollerton et al. 2011). The annual global pollinationdependent crop production has an estimated value of $\$ 170$ billion (Gallai et al. 2009) and is expected to rise (Aizen et al. 2008). With more than 20,000 described species (Ascher and Pickering 2016), wild bees make a substantial contribution to the increase of fruit set in crops and make yield less variable even in the presence of honey bees (Garibaldi et al. 2011b, 2013; Leonhardt et al. 2013). Managed pollinator species cannot replace their wild relatives (Tylianakis 2013), because the latter provide a key ecosystem service that is also essential for sustaining biodiversity of other organisms, including flowering plant communities (Potts et al. 2010).

World-wide reports of pollinator declines (Biesmeijer et al. 2006; Williams et al. 2009; Potts et al. 2010; Cameron et al. 2011; Ollerton et al. 2014) raise increasing concerns about limitations in seed set and fruit production in agroecosystems (Klein et al. 2007; Garibaldi et al. 2011a, b). Multiple drivers of wild bee decline can act on various spatial scales ranging from local land-use change and unsustainable agricultural practices (Quintero et al. 2009; Brittain and Potts 2011; Rollin et al. 2015) to regional biological invasions of pathogens (Cameron et al. 2011) and non-native species (Ghazoul 2004), and continental-scale climate change (Hegland et al. 2009). While local factors of bee decline are relatively well known and potential mitigation strategies at a landscape scale have been outlined (Zurbuchen and Müller 2012), regional and continental-scale threats to bee diversity have only been marginally explored (Roberts et al. 2011; Kuhlmann et al. 2012). This paucity of large-scale studies reflects a shortage of comprehensive, taxonomically reliable distribution data for most geographic regions. Large-scale patterns of bee diversity and distribution and their primary determinants have been only partly described for relatively small sub-continental regions (Patiny and Michez 2007; Kuhlmann 2009; Patiny et al. 2009a) or on a coarse country scale (Patiny et al. 2009b; Leonhardt et al. 2013; Nieto et al. 2014), but are essential for identifying target areas for conservation actions and developing effective global strategies for bee conservation. So far, global distribution data have been analyzed for only a few large and conspicuous taxa (e.g. bumble bees, Williams 1998; Williams et al. 2015) that in their life history and biogeographic patterns are not representative of the majority of bees.

As a model taxon for the present study we chose the bee subfamily Colletinae Lepeletier de Saint Fargeau (sensu Almeida and Danforth 2009), a monophyletic taxon comprising the genera Colletes Latreille and Mourecotelles Toro \& Cabezas (Colletidae) because of its nearly global distribution (absent from Australia, Madagascar, lowlands of SE Asia; Michener 2007) from the tropical lowlands to arctic and alpine environments (e.g. 
Kuhlmann 2005; Niu et al. 2013; Kuhlmann and Proshchalykin 2014). While Mourecotelles (sensu Michener 2007) is a relatively small genus of 22 described species endemic to temperate, especially xeric, southern South America (Fig. S1.1; Michener 2007), Colletes is the seventh most species-rich bee genus, with currently 494 described species (Ascher and Pickering 2016) and an estimated total of about 700 species (Kuhlmann and Proshchalykin 2014). Colletes are ground-nesting solitary bees that have been extensively studied by one of us (MK, comprehensive revisionary studies of the Old World fauna) over more than 20 years and involve species that differ in seasonality, soil preference and degree of floral specialization (Müller and Kuhlmann 2008) making it an ideal model representative of the vast majority of bees. Anecdotal evidence suggests that Colletes diversity, like that of many other bee genera and of bees in aggregate (Michener 1979, 2007), follows a reverse latitudinal diversity gradient with amphitropical peaks at mid-latitudes in Africa and Eurasia (Kuhlmann 2005, 2009) as well as North America and South America (e.g., many species in Chile and Argentina but few in equatorial South America, Moldenke 1976) but quantitative analyses are required to test and more precisely characterize this observation.

The present study is appropriate and timely, because it is based on a comprehensive dataset uniquely available for a species-rich group of wild bees on a global scale. Colletinae distribution records were assembled from museum specimen data digitized by the authors (after making or verifying species identifications), published information and existing databases. Given taxonomic and sampling challenges faced by those involved in bee research, it is unlikely that a substantial body of new knowledge about distribution of Colletinae will be created in the foreseeable future. The relationship between multiple environmental variables and patterns of bee species richness was tested by multiple regression. Our choice of environmental variables was driven by the need to address major stress factors on the continental to global scale. A close relationship between the contemporary climate and species diversity has been reported in several studies (Kleidon and Mooney 2000; Hawkins and Porter 2003; Vázquez-Rivera and Currie 2015); to reflect potential threat to bee diversity from climate change we tested several climatic variables potentially limiting foraging opportunities for bees. The second group of variables addressed habitat heterogeneity; bee diversity is expected to decline if the diversity of habitats, and consequently the diversity of food sources, declines (Hawkins and Porter 2003; Fründ et al. 2010, but see Hawkins and Porter 2003). The third group of variables included those related to potential pressures from agricultural expansion, land-use change and escalating human infrastructure; this group also included conservation opportunities. With this in mind we asked the following research questions: (1) What are the large-scale patterns and determinants of Colletinae species richness and endemism? (2) What are the major threats to Colletinae diversity on continental to global scales?

\section{Materials and methods}

\section{Bee data}

Bee data were assembled from various digital resources and unpublished original data digitized by the authors and checked for taxonomic and geographic errors. For Palaearctic and Afrotropical Realms distribution records originate from the database of MK that is based on verified published information including type data and specimens identified from private and public collections over the last $>20$ years. The Nearctic (including type data 
compiled by JSA) and Neotropical data are derived from the USDA-ARS Pollinating Insects Research Unit's U.S. National Pollinating Insects Collection (BBSL), the American Museum of Natural History (AMNH) and other members of the Digital Bee Collections Network (Table S1.1 in Online Resource 1). Additional Colletes data for the United States (only georeferenced specimens identified to species level) were accessed through Biodiversity Information Serving Our Nation (BISON, http://bison.usgs.ornl.gov, retrieved 2015-06-22) and complemented by Canadian records provided by the Royal Saskatchewan Museum, Regina, Canada. For details of the origin of data see Table S1.1 in Online Resource 1.

In total, over 45,000 records, nearly 18,000 of them being unique collection localities encompassing 707 taxa (species and morphospecies; 220 of them undescribed/morphospecies) were gathered and the unique collection localities were used for data analyses (Table S1.2 in Online Resource 1). The final dataset included the entire distributional range of Colletinae but geographic coverage varied considerably because comprehensive faunistic data were available only for a few regions. For the Neotropical Realm, except for a single regionally restricted review (Ferrari and Silveira 2015) Colletes data were especially patchy due to the lack of taxonomic revisions, particularly for the species rich areas of NW Argentina and Mexico (Michener 1979, 2007). In order to maximize the number of species recorded from this region without making duplicates, records of described but unrevised Colletes species of uncertain taxonomic status only known from the type material were excluded. Instead, one of us (TG) developed a consistent system of morphospecies, many of them apparently undescribed, based primarily on female bees of specimens not assignable to described species. Males were only assigned to additional morphospecies when they clearly did not correspond to any of the female morphospecies.

\section{Measurements of species richness and endemism}

All statistical analyses were carried out in R v.3.1.2 (The R Foundation for Statistical Computing).

Measurements of global species richness and endemism were carried out using Behrmann equal area cylindrical projection. We aggregated global observation data to $110 \times 100 \mathrm{~km}, 220 \times 220 \mathrm{~km}$ and $550 \times 550 \mathrm{~km}$ grid cell prior to analysis. We investigated the effect of coastal cells that span a very small fragment of land on species richness and weighted endemism in $550 \times 550 \mathrm{~km}$ grid cells by excluding all cells with $12 \%$ land area or less. In regional analyses, we used $110 \times 110$ grid cell size only. For these regional analyses four zoogeographic realms were delimited following Holt et al. (2013). For the purposes of the present study, Panamanian realm was included in the Neotropical, and Saharo-Arabian, Sino-Japanese and Oriental Realms of Holt et al. (2013) were combined with Palaearctic Realm because they represent a single Colletes fauna (Fig. S1.2 in Online Resource 1). Global species richness was measured as the total count of species within each grid cell. For the regional analyses, species richness was measured as per cent of the total number of species recorded in the realm, enabling comparison of the relative importance of hot-spots of bee richness between realms. In the case of taxa that spanned regions, only the proportion of a range falling within the corresponding region was used.

Weighted endemism (sensu Crisp et al. 2001) was measured by weighting species richness in each cell by the inverse of the range size of each species calculated as the number of grid cells occupied; as a result, species that occur over smaller ranges were given higher scores. Although alternative measures of weighted endemism designed for 
regions comprising many cells and polygonal regions (Laffan and Crisp 2003; Laffan et al. 2013) exist, the analysis based on individual grid cells used in our study is justified by a relatively coarse grid cell size and limited knowledge about species ranges due to incomplete sampling.

Calculations of weighted endemism were made using self-contained $\mathrm{R}$ function developed by Guerin et al. (2015) with cell weights defined as "cell-based". Thus we effectively ignored spatial spread of individual cells occupied by species (i.e. the chosen approach did not distinguish between occurrence within a number of adjacent grid cells and occurrence within the same number of grid cells scattered across the area of interest); in this study such approach is justified by the presence of a relatively large number of species represented by a single collection locality (176 out of 707, or $25 \%$ of all taxa, see Fig. S1.3 in Online Resource 1) and expected to be geographically restricted, in the case of species collected from a single locality, to one grid cell. To determine the expected null distribution of endemism for each observed value of species richness we ran the statistical tests (as implemented by Guerin et al. 2015) with 1000 replicates. Specifically, for each value of observed species richness, the expected null distribution of endemism was determined by taking 2000 random draws of that number of species from the overall pull; this null distribution was compared to the observed weighted endemism score to estimate statistical significance of the observed score being higher or lower than expected (Guerin et al. 2015).

Spatial distribution of the sampling was estimated using a sample redundancy index (Garcillán et al. 2003). For the purposes of the present analysis, the index is defined as the ratio of species to the total number of samples in a grid cell. Because the ratio is subtracted from one, values close to one indicate well sampled cells while the values close to zero indicate that each species was sampled only once. Following Laity et al. (2015), we defined cells with the redundancy scores above 0.3 as well sampled. The index was calculated for the dataset with over 45,000 records representing collecting events and/or specimens.

\section{Environmental data}

Williams et al. (2015) identified climatic variables that were meaningful for interpreting distribution of Tibetan bumble bees. The variables were selected based on their impact on diurnal foraging activity of bumble bees and host plant availability. Tibetan bumble bees have relatively short seasonal activity patterns and foraging requirements comparable to those typical for solitary bees like Colletes (Kuhlmann 2002; Niu et al. 2013, 2014). Adult females of Colletes are active during 2-3 months (Michener 2007). The analysis of specimen labels shows (MK, pers.obs.) that for the vast majority of Colletes species the main period of activity coincides with the warmest quarter; the phenology of individual species can vary depending on latitude and climate zone (Noskiewicz 1936; Stephen 1954; Westrich 1989). In the present study, we focus on the variables that affect foraging activity and flower availability during the most important time for foraging and reproduction for the vast majority of species, the warmest quarter (Table 1).

In the present study, in addition to several Bioclim (Hijmans et al. 2005) variables (mean temperature of the warmest quarter, irradiance in the warmest quarter, precipitation of the wettest month and warmest quarter) we used a measure of summer temperature accumulation (growing degree days) and a measure of water deficit (Table 1). All selected variables plausibly affect bee reproductive success and survival during the main season of activity of the adult Colletes bees (Table 1). As a proxy for the diversity of foraging resources, we used global vascular plant diversity (Barthlott et al. 1996, 2007) and the 


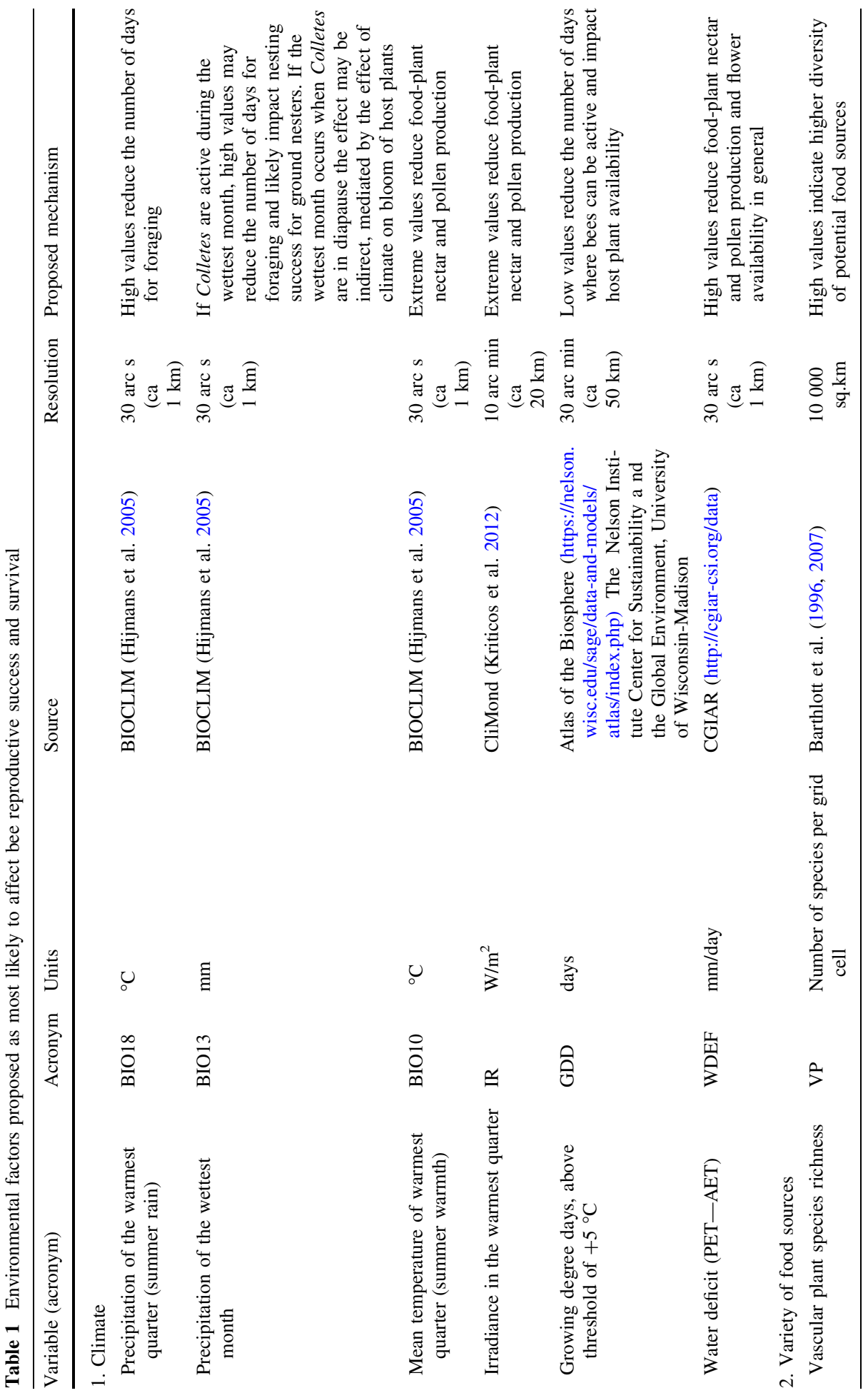




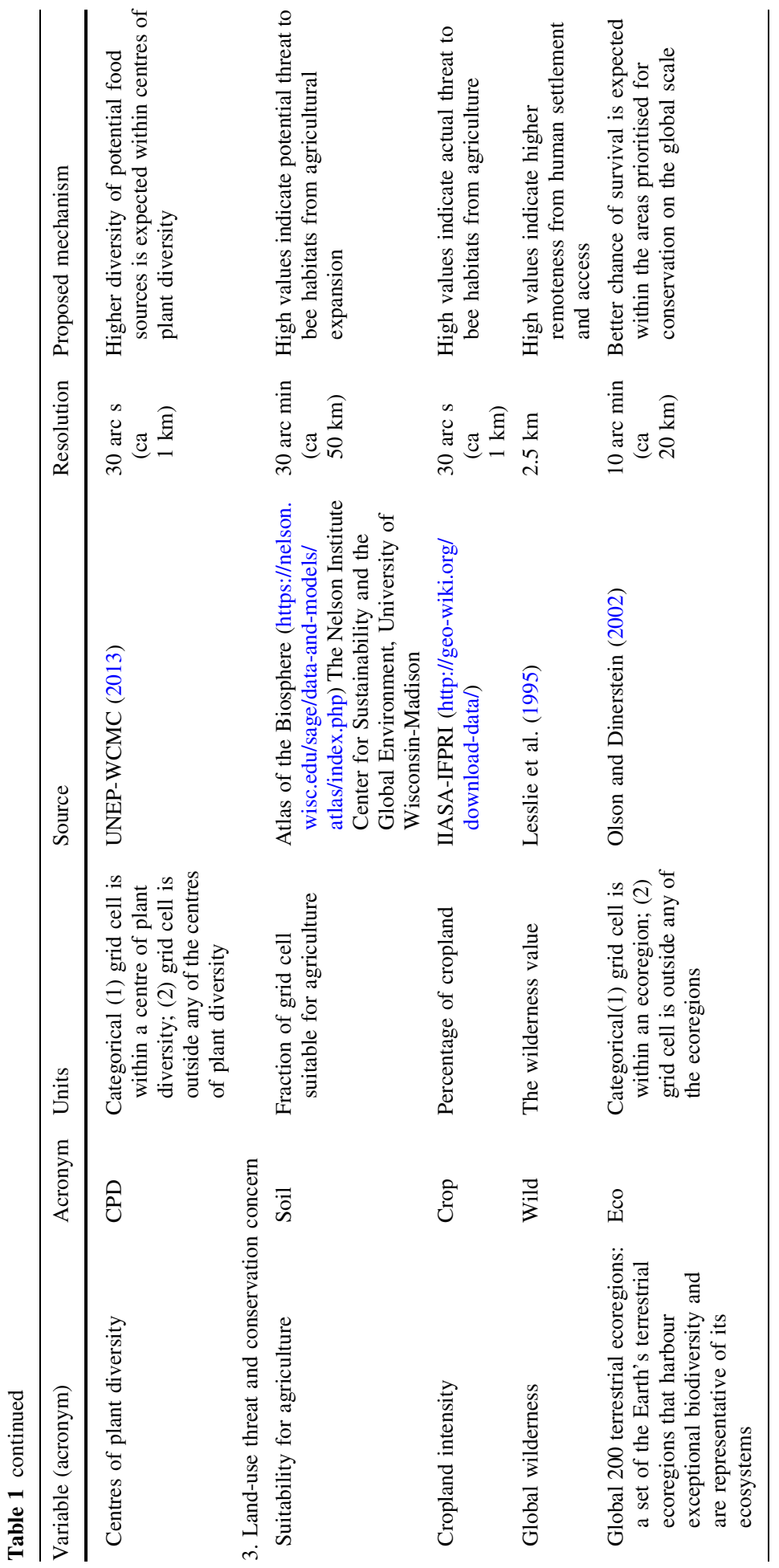


global distribution of centres of plant diversity (UNEP-WCMC 2013). To address potential threat from land-use change, we used a measure of agricultural suitability of soils (reflecting potential land transformation, habitat destruction, use of pesticides, etc.), a measure of cropland intensity, and a measure of remoteness from human influence (wilderness) assessed on the basis of remoteness from settlement (settled land or points of permanent occupation), from access (constructed vehicle access routes), and apparent naturalness (remoteness from permanent manmade structures) as defined by Lesslie et al. (1995). As a measure of potential for conservation prioritisation, we used a set of the Earth's terrestrial ecoregions, The Global 200 (Olson and Dinerstein 2002) that harbour exceptional biodiversity and are representative of its ecosystems. All variables were aggregated to the spatial scale of $1^{\circ}(110 \times 110 \mathrm{~km})$.

\section{Regression analysis}

Generalised linear models (GLMs) have proved useful as an exploratory tool in modelling distribution of insect species richness (Lobo et al. 2002). To model the relationship between bee species richness and environmental variables we used GLMs; they provide more flexibility when there is no a priori hypothesis about the shape of the relationship between the response and explanatory variables (Nelder and Wedderburn 1972). Because the Poisson distribution does not account for any extra variation in the data, we also considered the quasi-Poisson and negative binomial distributions (Ver Hoef and Boveng 2007). To identify the most appropriate type of model we compared modelling approaches following Zeileis et al. (2008). The negative binomial had the best fit to the data and was chosen for further analysis. Model fitting was carried out using packages "stats" and "MASS". The appropriateness of the model choice was also confirmed by the model selection procedure carried out using log-likelihood statistics (results not shown here). In all models, correlations between variables were below 0.77 (Figs. S1.4-S1.8 In Online Resource 1) The analysis was first carried out on the global scale, and then the strength of the same predictors was tested on regional subsets encompassing Palaearctic, Afrotropical, Nearctic and Neotropical Realms (as defined by Holt et al. 2013). A strong right skew prevented us from transforming the dataset in such a way that the assumption of normality would be substantiated. However, the relatively large sample size (see Table S1.2 in Online Resource 1) releases the requirement of normality and renders highly significant coefficients $(\mathrm{p}<0.001)$ reliable (Lumley et al. 2002).

Autocorrelation is the lack of independence between pairs of observations at given distances in time and space, a common issue in ecological data (Landeiro and Magnusson 2011; Legendre 1993). In the presence of autocorrelation, type I errors (i.e. incorrect rejection of a null hypothesis) might be inflated in regression analysis. To evaluate the spatial structure of the bee richness data, we used a stand-alone software SAM (https:// www.ecoevol.ufg.br/sam/) designed for spatial statistical analysis of ecological data (Rangel et al. 2010). We calculated Moran's I coefficient (Legendre and Legendre 1998) in distance classes the size of which was defined by equal numbers of pairs; the approach generates more comparable Moran's I coefficients (Diniz-Filho et al. 2003). To find out if the regression approach employed in our study resolved the problems associated with significance testing, we calculated Moran's I in the residuals of the GLMs defined as the difference between observed and predicted values for each cell. 


\section{Results}

\section{Global richness and endemism patterns and macroecological analysis}

To reduce the effect of incomplete sampling, we chose $550 \times 550 \mathrm{~km}$ grid cell size to represent global patterns of species richness and weighted endemism (Figs. 1, 2, S2.1, $\mathrm{S} 2.2, \mathrm{~S} 2.3, \mathrm{~S} 2.4$ in Online Resource 2). At this scale, the effect of the removal of coastal cells on the resulting patterns of species richness and weighted endemism was negligible (Figs. S2.5, S2.6 in Online Resource 2). However, the effect was noticeable when the patterns of corrected weighted endemism were considered, in particular in the case of Northern and Central Americas (Figs. S2.7, S2.8 in Online Resource 2).

On the global scale, five species richness hot-spots were identified on a ca $5^{\circ}(550 \times$ $550 \mathrm{~km}$ ) grid: Mediterranean and Asia Minor-Caucasus Regions, Central Asia, South African Greater Cape Floristic Region (GCFR), Mojave/Sonoran Deserts and Central Chile/NW Argentina (Fig. 1). The GCFR stood out as an overall centre of species richness with as many as 59 species per $5^{\circ}$ grid cell. The global weighted endemism patterns were largely consistent with those of richness (Fig. 2); however on the global scale the Mediterranean area turned out to be relatively unimportant in terms of weighted endemism due to a large number of species in common with Central Asia.

The results of the tests of deviance based on null expectations revealed a number of cells where observed endemism values were significantly different from the expected null distribution of endemism for each observed value of species richness. Specifically, the identified global hotspot in the GCFR as well as centres of endemism in North, Central and South America had significantly (at 0.025 probability level) higher endemism values than would be expected assuming a null distribution (see Fig. S2.9 in Online Resource 2).

The analysis of spatial distribution of the sampling indicated that there was a good degree of sampling redundancy on the global scale (Figs. S2.10, S2.11 in Online Resource $2)$, in particular on a ca $5^{\circ}(550 \times 550 \mathrm{~km})$ grid; thus sampling bias was unlikely to influence the results of spatial analysis.

The final regression model for global extent explained nearly $25.7 \%$ of the total deviance and was built with six variables making statistically significant contribution to the model (Tables 2, S2.1, S2.2 in Online Resource 2). Bee species richness was positively

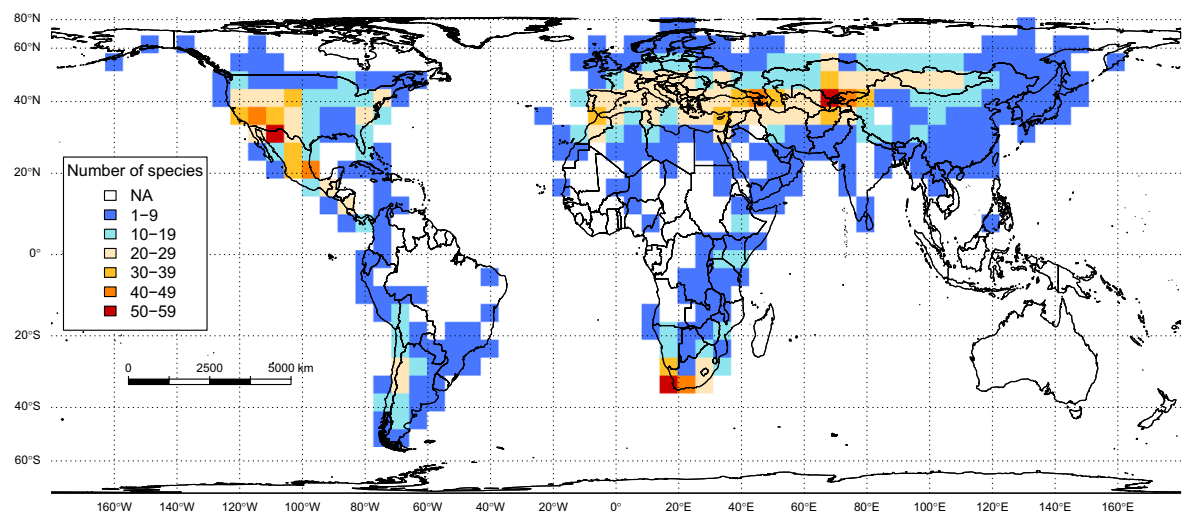

Fig. 1 Global patterns of species richness (number of species) of Colletinae on a ca $5 \times 5(550 \times 550 \mathrm{~km})$ degree grid. Map projection: Behrmann equal area 


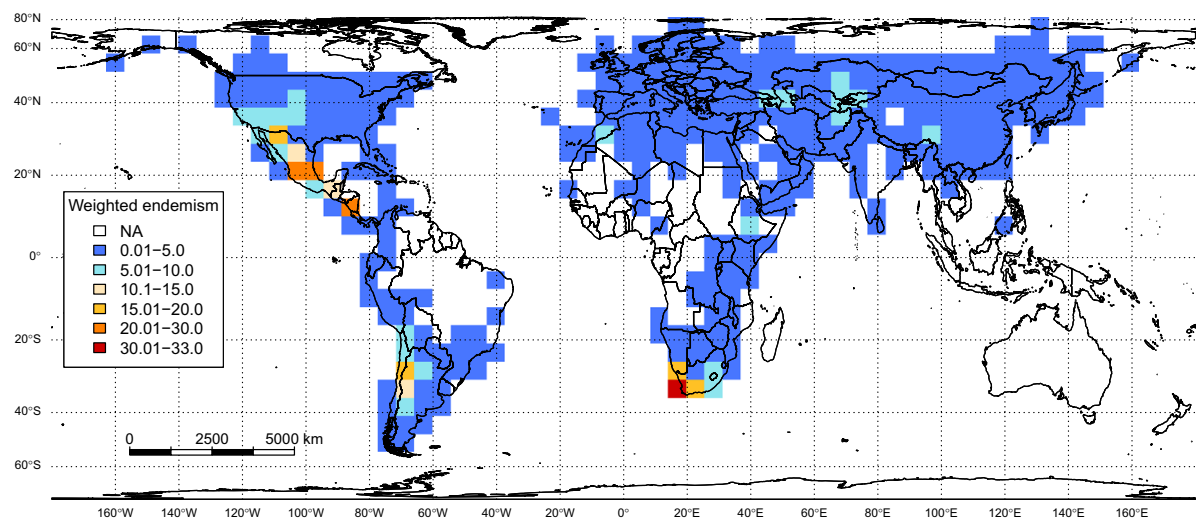

Fig. 2 Global patterns of weighted endemism (sensu Crisp et al. 2001) of Colletinae on a ca $5 \times 5(550 \times$ $550 \mathrm{~km}$ ) degree grid. Map projection: Behrmann equal area

Table 2 Regression coefficients and standard errors (in brackets) for the generalised linear models (negative binomial) fitted to the species richness values (on ca $1^{\circ}$ ) of Colletinae bees limited by the Palaearctic, Nearctic, Afrotropical, Neotropical and global extents

\begin{tabular}{|c|c|c|c|c|c|}
\hline Extent & Palaearctic & Nearctic & Afrotropical & Neotropical & Global \\
\hline \multicolumn{6}{|c|}{ 1. Climate } \\
\hline BIO18 & Not used & Not used & NS & NS & Not used \\
\hline BIO13 & $-0.17(0.04)$ & $-0.21(0.05)$ & Not used & Not used & $-0.16(0.03)$ \\
\hline BIO10 & Not used & Not used & NS & $-0.20(0.06)$ & Not used \\
\hline IR & $0.24(0.03)$ & $0.22(0.04)$ & NS & $0.37(0.06)$ & $0.27(0.02)$ \\
\hline GDD & $-0.12(0.03)$ & NS & $-0.28(0.04)$ & Not used & $-0.12(0.02)$ \\
\hline WDEF & NS & NS & NS & NS & NS \\
\hline \multicolumn{6}{|c|}{ 2. Variety of food sources } \\
\hline VP & $0.14(0.03)$ & $0.43(0.04)$ & $0.17(0.04)$ & $0.30(0.06)$ & $0.28(0.02)$ \\
\hline CPD & $0.34(0.06)$ & $0.3(0.1)$ & $0.4(0.1)$ & NS & $0.31(0.05)$ \\
\hline \multicolumn{6}{|c|}{ 3. Land-use threat and conservation concern } \\
\hline Soil & $0.10(0.02)$ & $-0.20(0.04)$ & Not used & NS & NS \\
\hline Crop & NS & NS & NS & NS & NS \\
\hline Wild & $-0.13(0.02)$ & $-0.11(0.04)$ & NS & $-0.17(0.05)$ & $-0.12(0.02)$ \\
\hline
\end{tabular}

Acronyms of climatic variables as in Table 1. "NS": estimate was not significant at 0.05 level; "Not used": variable was not used in the maximal model because it was highly correlated with other variable(s)

associated with irradiance (IR) and total diversity of vascular plants (VP), and was higher in the centres of plant diversity (CPD); it was negatively associated with precipitation of wettest month (BIO13), growing degree days (GDD) and index of wilderness (Wild). Global values of spatial autocorrelation measured by Moran's I for species richness in 110 $\times 110 \mathrm{~km}$ grid cells varied in the range $-0.046-0.147$ (Table S2.3, in Online Resource 2). There was positive autocorrelation in short distance classes, coupled with negative autocorrelation at large distance classes (Table S2.3 in Online Resource 2). The residual value 
of spatial autocorrelation did not exceed 0.05, although some of the Moran's I values were statistically significant (Table S2.3 in Online Resource 2); thus a small amount of spatial structure remained unaccounted for.

\section{Regional species richness and endemism patterns and macroecological analysis}

The most species-rich realm was the Palaearctic with 234 species (Figs. 3, 4) followed by the Nearctic with 190 species/morphospecies (Figs. 5, 6), the Afrotropical with 157 species (Figs. 7, 8), and the Neotropical with 153 species/morphospecies (Figs. 9, 10). Relative species richness (expressed as per cent of the total number of species described in the realm) ranged from 11.1 to 11.8 in the Neotropical and Palaearctic realms to 21 in the Afrotropical Realm (Figs. 3, 5, 7, 9). Weighted endemism patterns were generally consistent with those of species richness; the highest value (13.5) was found in the Afrotropical Realm (Fig. 4). In all realms, some of the observed endemism values were significantly different from the expected null distribution of endemism for each observed value of species richness (Figs S2.12-S2.15 in Online Resource 2).

Of all climatic variables used for regression analysis three (precipitation of warmest quarter, BIO18; water deficit, WDEF; and cropland intensity, Crop) did not significantly contribute to any of the models fitted to the regional counts of species richness (Tables 2, S2.4-S2.7 in Online Resource 2). Precipitation of wettest month (BIO13) and growing degree days (GDD) were consistently negatively associated with bee species richness in two regional models each, while irradiance (IR) was consistently positively associated with species richness. Diversity of vascular plants (VP) and centres of plant diversity (CPD) were consistently positively associated with bee species richness in all models except for in the Neotropical Realm where CPD was not significant. The third category of variables approximating land-use threat and conservation concern was represented by three statistically significant variables associated with bee species richness (Table 2): global index of wilderness (Wild) negatively associated with species richness in three regions; Global 200 terrestrial ecoregions (Eco) positively associated with species richness in the Palaearctic; and suitability of soil for agriculture (Soil) negatively associated with species richness in the Nearctic, but positively, in the Palaearctic. The amount of explained variance ranged

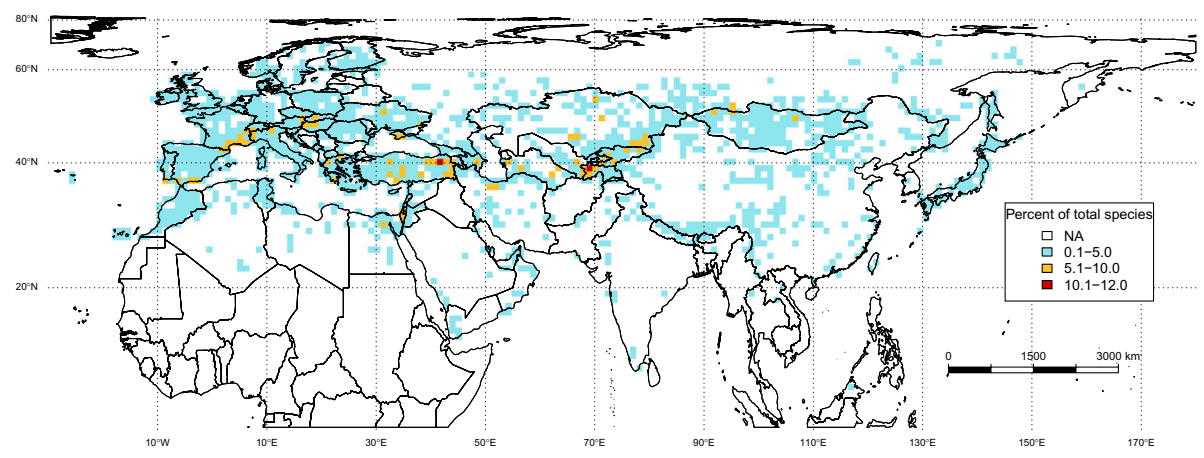

Fig. 3 Palaearctic realm: species richness of Colletinae. Species richness is presented as per cent of the total number of species recorded in the region (234) on a ca $1.0^{\circ}$ grid. The most species-rich grid squares (in yellow) have up to $11.1 \%$ of the total species recorded in the region. Map projection: Behrmann equal area. (Color figure online) 


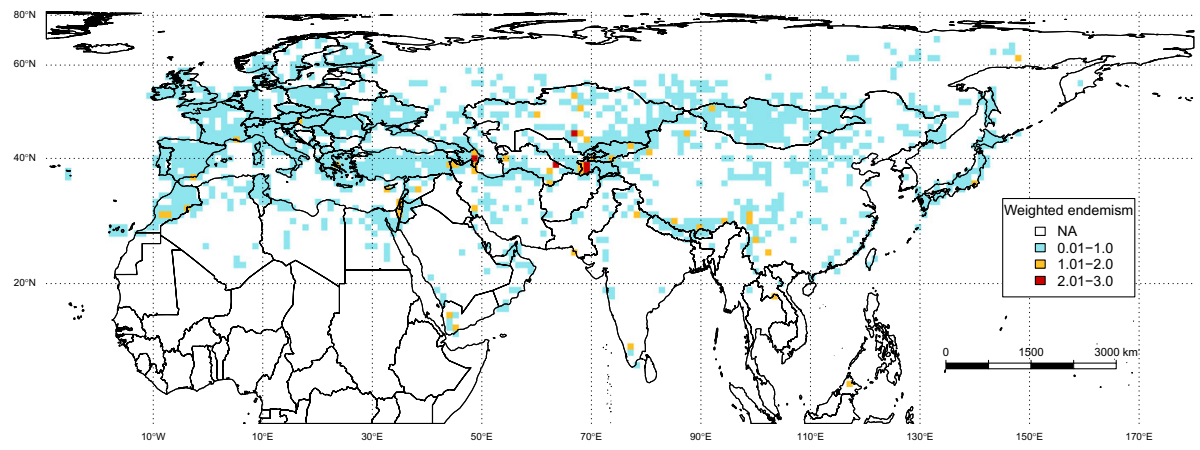

Fig. 4 Palaearctic realm: weighted endemism of Colletinae on a ca $1.0^{\circ}$ grid. Map projection: Behrmann equal area

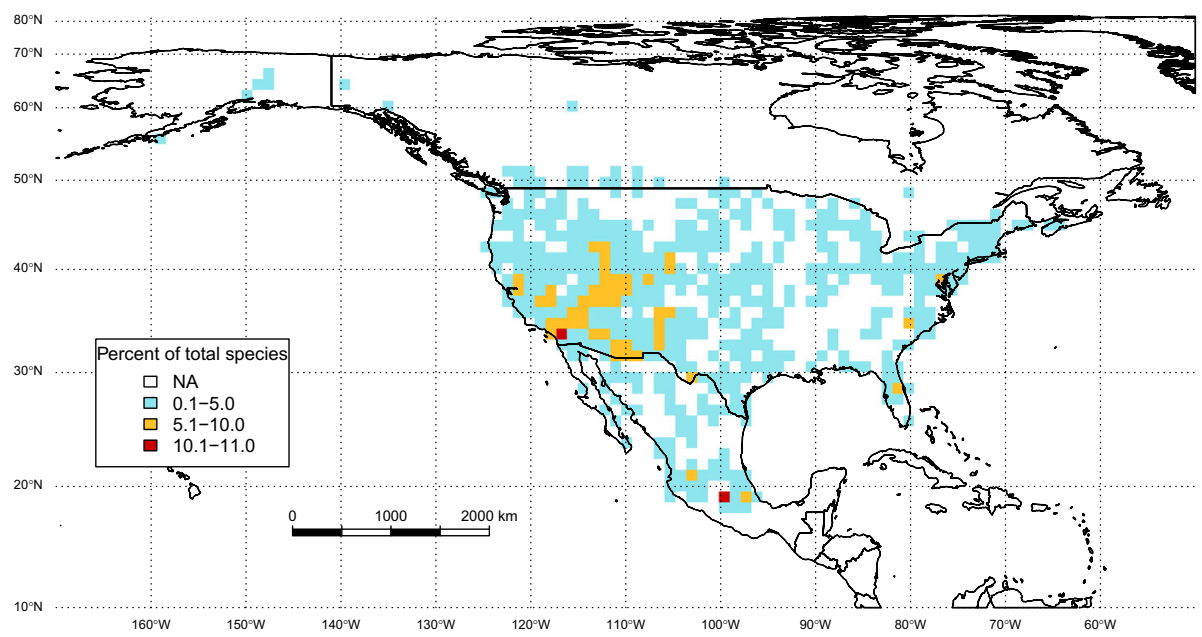

Fig. 5 Nearctic realm: species richness of Colletinae. Species richness is presented as per cent of the total number of species recorded in the region (190) on a ca $1.0^{\circ}$ grid. The most species-rich grid squares (in yellow) have up to $10.5 \%$ of the total species recorded in the region. Map projection: Behrmann equal area. (Color figure online)

from $19.3 \%$ in the Neotropical Realm to $33.6 \%$ in the Nearctic. The residual value of spatial autocorrelation did not exceed 0.064 in any of the regional models, although some of the Moran's I values were statistically significant (Tables S2.8-S2.11 in Online Resource 2); thus a small amount of spatial structure remained unaccounted for.

\section{Discussion}

\section{Patterns of bee species richness and endemism}

A general pattern of declining species diversity from the equator towards the poles holds on the global scale across multiple groups of organisms (Allen et al. 2002; Hillebrand 


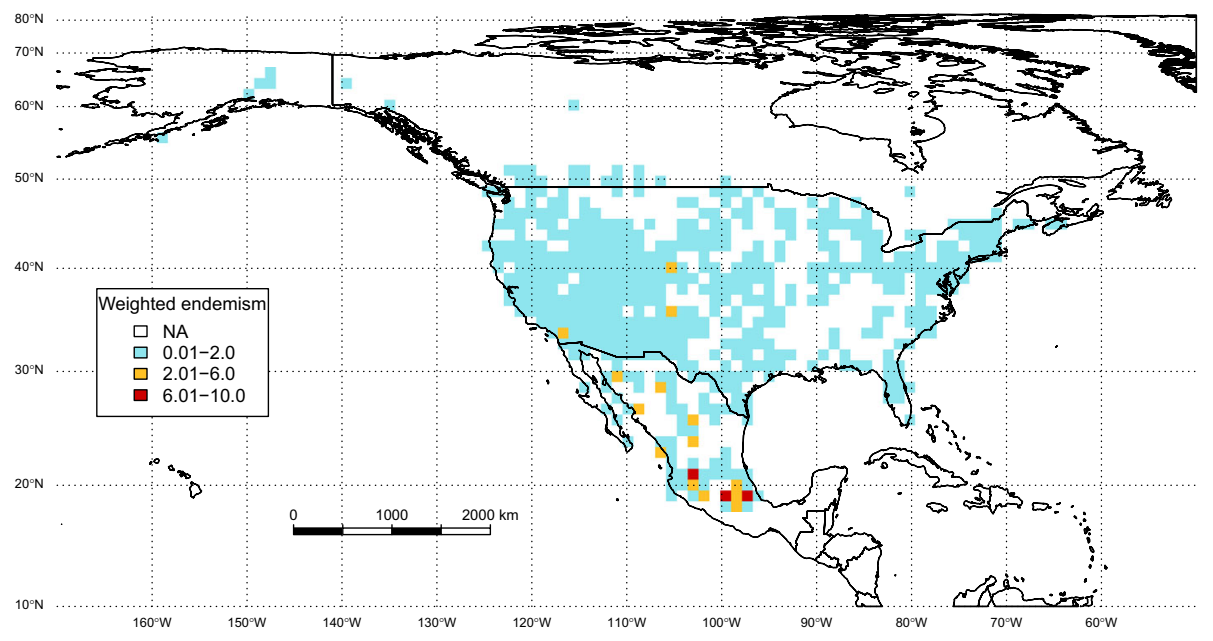

Fig. 6 Nearctic realm: weighted endemism of Colletinae on a ca $1.0^{\circ}$ grid. Map projection: Behrmann equal area

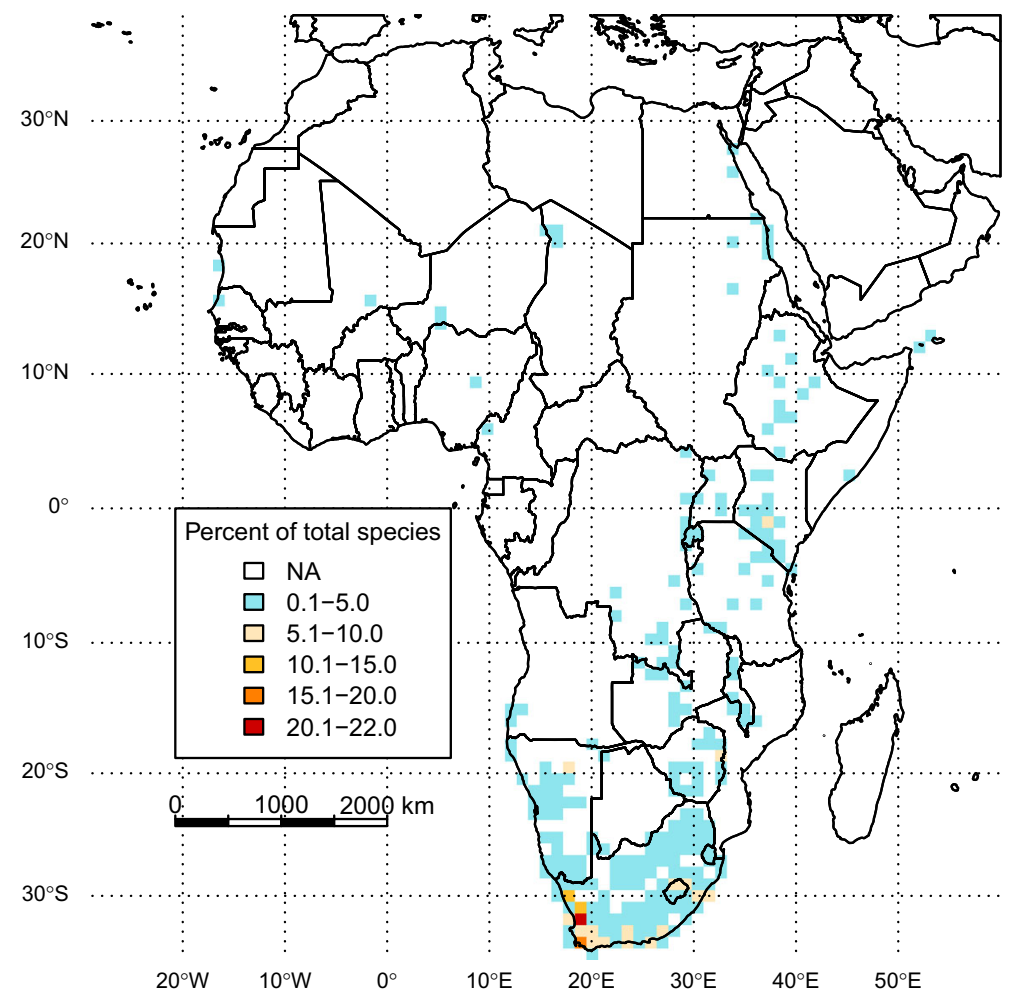

Fig. 7 Afrotropical realm: species richness of Colletinae. Species richness is presented as per cent of the total number of species recorded in the region (157) on a ca $1.0^{\circ}$ grid: the most species-rich grid square (in dark red) has $21 \%$ of the total species recorded in the region. Note that the most species rich square is also a hot-spot of endemism (see Fig. 9). Map projection: Behrmann equal area. (Color figure online) 


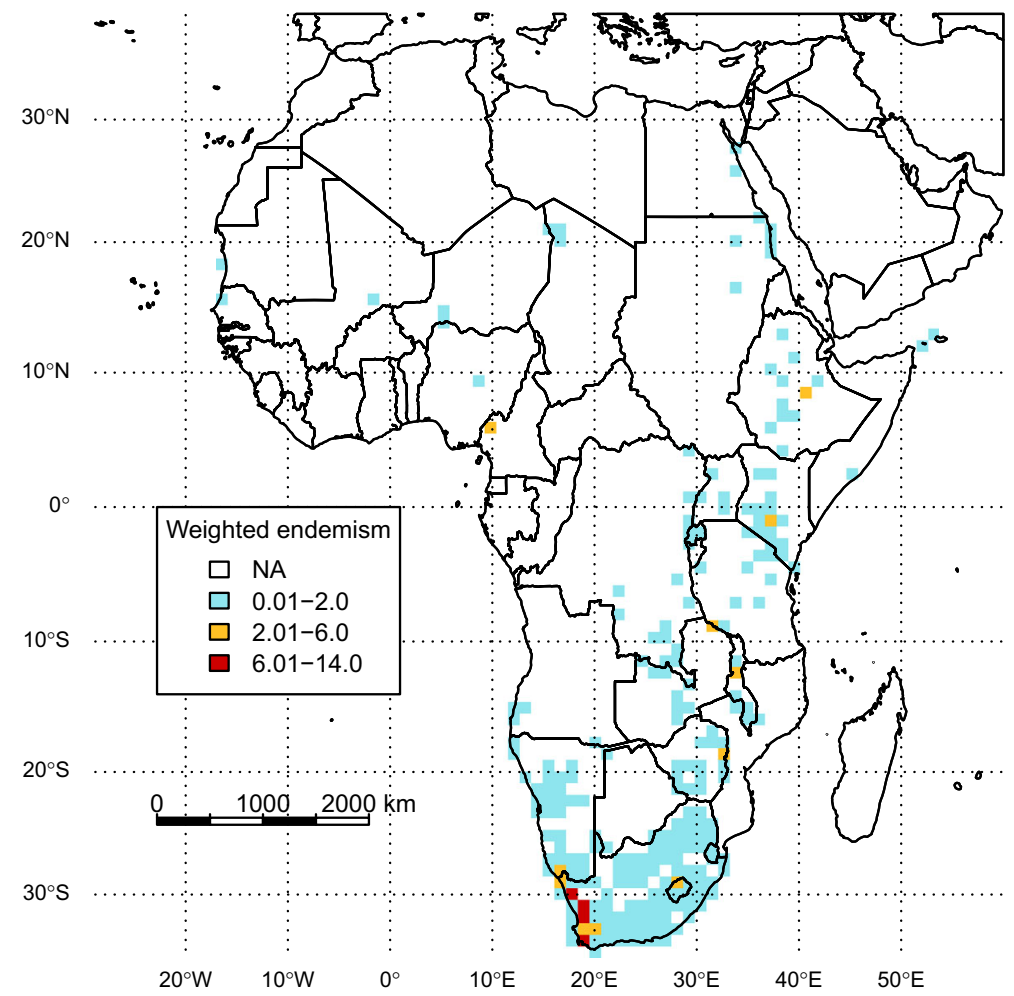

Fig. 8 Afrotropical realm: weighted endemism of Colletinae on a ca $1.0^{\circ}$ grid. Map projection: Behrmann equal area

2004; Mittelbach et al. 2007) including terrestrial arthropods (Lewinsohn and Roslin 2008), but there are notable exceptions among vertebrates (Grenyer et al. 2006), gymnosperms (Fragnière et al. 2015), as well as some insect groups like aphids (Dixon et al. 1987) and sawflies (Kouki et al. 1994). Solitary bees appear to provide yet another example of such a reversed latitudinal gradient in species richness and endemism. The global analysis carried out in our study confirmed Mediterranean and Asia Minor-Caucasus region, Central Asia, GCFR, Mojave/Sonoran Deserts and Central Chile/NW Argentina as species richness hot-spots on a ca $5^{\circ}(550 \times 550 \mathrm{~km})$ grid. Thus the highest species richness of Colletinae was not found in the tropics, as would be expected according to the general pattern of diversity, but between $30^{\circ}$ and $50^{\circ}$ in both the northern and southern hemispheres. The richness patterns observed in Colletinae are consistent with those generally assumed for solitary bees. Significant taxonomic problems prevent proper detailed interpretations of diversity for other taxa with similar characteristics (e.g. Hylaeinae, Ceratina, Lasioglossum) and global distributions (Michener 1979, 2007). Regarding other bee taxa, so far global patterns of diversity and endemism have only been analyzed for bumble bees (Williams 1998; Williams et al. 2014). However, Bombus is much less diverse (about 260 species) and more importantly is predominantly distributed in mountainous regions and higher latitudes of the northern hemisphere, hence it is not representative of the majority of bees (Michener 2007). 


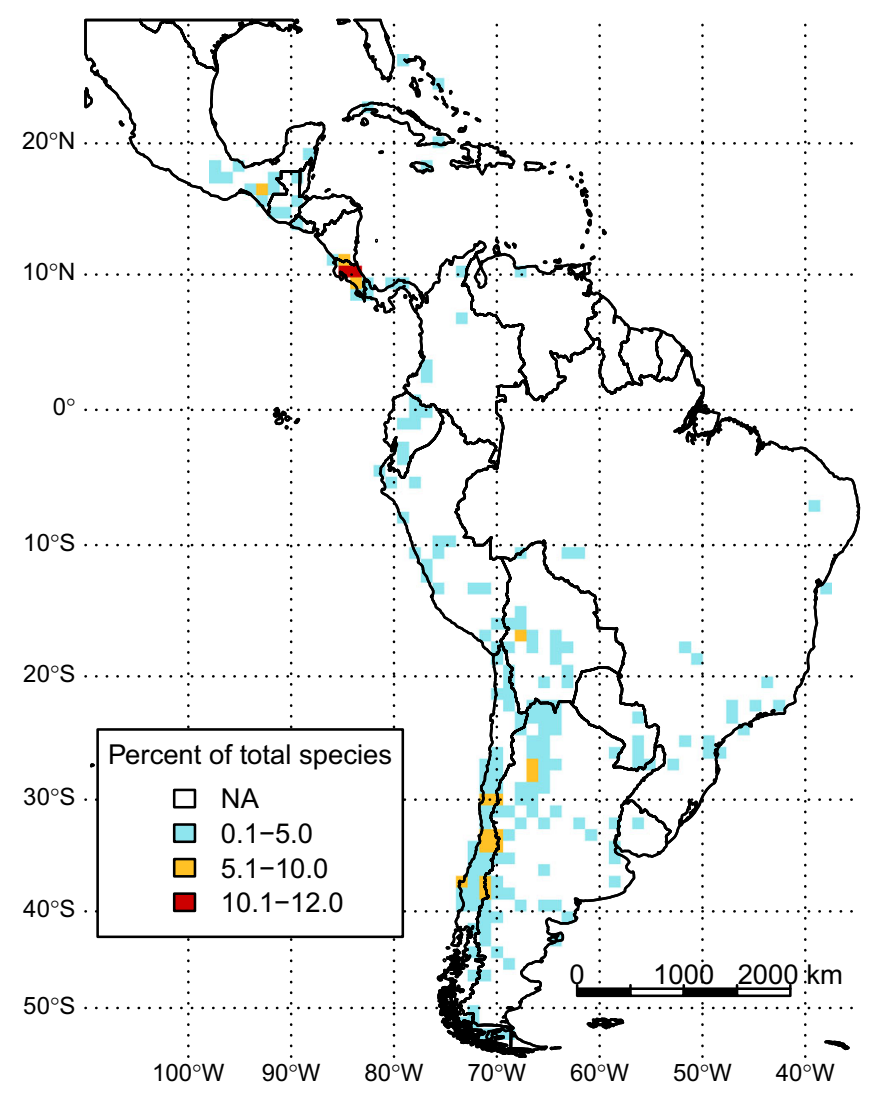

Fig. 9 Neotropical realm: species richness of a subset of Colletinae. Species richness is presented as per cent of the total number of species recorded in the region (153) in a ca $1.0^{\circ}$ grid cell. The most species-rich grid squares (in red) have up to $11.8 \%$ of the total species recorded in the region. Map projection: Behrmann equal area. (Color figure online)

Previous assessments (Michener 1979) identified global peaks of bee diversity in Mediterranean and desert environments characterized by warm to hot and dry summers, and mild to cool winters with some precipitation, with bees as a whole less diverse in tropical areas, particularly in the Eastern Hemisphere. There are, however, bee groups that are most diverse in the equatorial tropics such as the Pantropical, highly eusocial stingless bees (Meliponini) and the exclusively New World and primarily Neotropical Euglossini and Augochlorini. These three tribes collectively total only 1355 described species $(6.7 \%$ of described bee species), and together with other tropical-adapted bee lineages represent a minority of the total bee species diversity (Michener 1979, 2007).

Globally, areas of high endemism (calculated as weighted endemism) were found in midlatitudes and largely overlapped with centres of species richness (Figs. 1, 2). The GCFR stood out, with the highest score of weighted endemism globally. Thus, the importance of this region, already identified as a centre of richness and endemism of bees (Kuhlmann 2009), was confirmed. Other globally prominent and previously recognized hot spots of species diversity and endemism are Central Asia, the Caucasus region and the southwestern USA and adjacent northern Mexico (Michener 1979, 2007; Kuhlmann 2005 ). The importance of temperate 


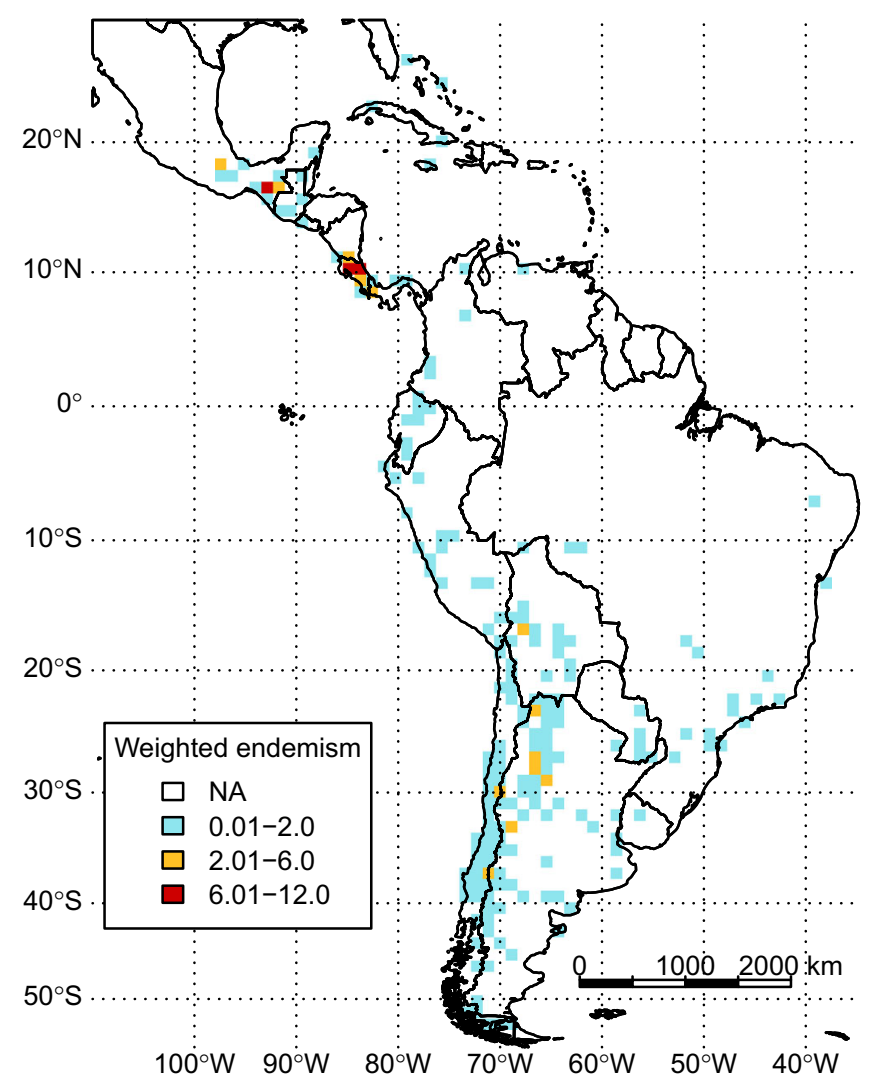

Fig. 10 Neotropical realm: weighted endemism of a subset of Colletinae in a ca $1.0^{\circ}$ grid cell. Map projection: Behrmann equal area

South America, where Mourecotelles is endemic (Michener 2007), is underestimated in our analyses due to lack of revisionary studies of the Colletes of Argentina and corresponding scarcity of reliably determined specimens in collections. The Chilean fauna is better known but there are still gaps, especially for historically undersampled northern Chile.

Within taxa, richness and endemism tend to be highly correlated (e.g. Kerr 1997; Crisp et al. 2001). Consistent with earlier observations, our study discovered a strong association (Spearman's correlation coefficient of 0.76) between species richness and endemism in Colletinae; both variables follow roughly similar log-normal distribution, characterised by strong right-skew typical for a variety of taxa (Gaston et al. 1998). Consequently, a species-rich site could end up with a higher score of endemism despite having the same number of rare species if widespread species are also present (Williams 2000). In our study, the highest values of endemism exceeded the expected values based on a null distribution, suggesting that the results of the endemism analysis are unlikely to be due to a random assemblage. 


\section{Drivers of species richness and conservation perspective}

Present-day climate was a predictor of species richness in all models, with statistically significant climatic variables also ecologically meaningful. Specifically, in all models but one, precipitation of the wettest month was negatively correlated with bee species richness; wet climates with increased humidity are likely to cause problems for food storage in brood cells and nest construction for soil nesters (Michener 1979). To the extent that high precipitation in the wettest month correlates with overall high rainfall it may also cause reduction in foraging opportunities. Interpretation of the relationship between energy variables (irradiance of the warmest quarter, mean temperature of warmest quarter and growing degree days) and species richness is less straightforward. For example, growing degree days, contrary to expectations, were negatively related to species richness, probably due to the fact that in some areas high energy levels are linked to the most extreme deserts (e.g. northern Atacama, Sahara) or are found in the moist tropics, both unfavourable for bees. Areas too xeric for optimal bee diversity are extensive in the Afrotropical and Palaearctic Realms where the relationship between growing degree days and species richness was significantly negative and where bee diversity appears to be driven by optimal (rather than maximal) ecosystem energy (Patiny et al. 2009a). Irradiance of the warmest quarter, on the other hand, was positively related to bee richness on the global scale, and in the Neotropical, Nearctic and Palaearctic Realms. Although both irradiance and growing degree days are energy variables, correlations between them were weak in all datasets $(\mathrm{r}=0.51$ or less).

As climatic factors clearly have an influence on bee distribution, climate change can be expected to affect many bee species by causing spatial and/or temporal mismatch between plants and pollinators, and impact them through extreme weather events and shifts in distributional ranges (Memmott et al. 2007; Goulson et al. 2015). Roberts et al. (2011) demonstrated that three generalists and three specialist species of Colletes might be threatened by climate change, and for the global bee diversity hotspot of the GCFR, substantial range contraction for most bee species under a scenario of warming climate is predicted (Kuhlmann et al. 2012). In our study, the significant association of a number of climatic variables (precipitation of the wettest month, irradiance of the warmest quarter and growing degree days) with species richness estimates corroborates the results of the earlier studies and suggests that changing climate might have a direct effect on bee diversity at the global to regional scales (Williams et al. 2009; Pradervand et al. 2014; Scriven et al. 2015). Further, the directionality and relative importance of various climatic variables appears to be consistent across different scales and geographic regions; however area-specific differences cannot be ruled out. We argue that detailed studies of the potential effects of changing climate on bee diversity within each identified bee species richness hotspot will be essential to develop conservation programs adequate to preserve plantpollinator interactions (Memmott et al. 2007).

Variety of food sources represented by richness of vascular plants and centres of plant diversity was significant at all scales and appeared to be the strongest predictor of bee species richness as already presumed by Patiny et al. (2009a). For example, the global Colletinae species richness hot-spot in the GCFR coincides with one of the most prominent centres of plant diversity and endemism (Kuhlmann 2009). This is consistent with the findings of other studies focused on invertebrates (Schuldt et al. 2009; Fründ et al. 2010, but see Williams 1989; Hawkins and Porter 2003). It is unclear whether statistical correlations between diversity of vascular plants and richness of bees reflect direct cause- 
effect connections as might be expected from plant-pollinator relationship, because melittophilous plants form only a portion of the flora (Ollerton et al. 2011), and it is known that plant and bee richness do not routinely match (Michener 1979). Furthermore, the vascular plant diversity variable used here was produced by interpolation limiting its suitability for macroecological analysis (Barthlott et al. 2007). Further progress in our understanding of large-scale plant-pollinator relationships will remain a challenge without reliable estimates of vascular (and, in particular, melittophilous) plant diversity on the global scale.

Reduced diversity of flowering plants due to land use has been shown to have a negative effect on honey bees (Goulson et al. 2015) as well as wild bees (Williams 1986; Biesmeijer et al. 2006; Scheper et al. 2014). The assumption of functional complementarity (i.e. when species differ in their contribution to some collective function) as shown for honey bees and wild bees (Garibaldi et al. 2011a, 2013) suggests that higher floral diversity may better sustain the requirements of pollinators (Fründ et al. 2010; Blüthgen and Klein 2011). In spite of the limiting power of the plant diversity data, our study demonstrates for the first time the positive relationship between the variety of food sources and species richness of wild bees on a global scale.

Some of the variables chosen to represent land-use threat and general conservation concern were inconsistently related to bee richness. Thus, suitability of soil for agriculture was positively related to bee species richness in the Palaearctic but negatively in the Nearctic. Although cropland intensity has been shown to be an important predictor of vertebrate richness (Kehoe et al. 2015), it was not significant in any of our models. The inconsistent or insignificant relationships between bee richness and selected land-use variables are probably due to the relatively coarse scale of the analysis used in our study (Rollin et al. 2015). To fully understand the effects of land-use change on bee diversity, further data are required on how ecological traits mediate species responses to human pressures (De Palma et al. 2015).

The index of wilderness was negatively related to bee species richness in the global and three regional models, which could be interpreted as a close association of bees with anthropogenic habitats. However, reduced sampling in remote areas seems more likely to explain much of the observed pattern. Arid environments unsuitable for intensive agriculture (e.g. Mojave/Sonoran Deserts) can be hot spots of bee diversity, yet even here most sampling is conducted adjacent to human modified land. Alternatively, bees may thrive in some altered landscapes. Although bees can be diverse in urban environments (Fortel et al. 2014), land transformation and agriculture are the most important threats to the majority of bee species (Nieto et al. 2014). The coincidence of hot spots of bee richness with bee endemism (except in the Mediterranean), and their overlap with global biodiversity hot spots (Myers et al. 2000) and partly with areas designated as The Global 200 terrestrial ecoregions (Olson and Dinerstein 2002) provides the opportunity for combined conservation efforts targeting other useful and/or iconic plants and animals.

\section{Limitations of the study}

This study is unique in being the first global-scale analysis of the distributional pattern and key environmental determinants of a large, widely-distributed, and representative group of ground-nesting bees. However, Australia is not covered by this study since Colletinae do not occur there.

Because the majority of the data used in the study were sourced from biological collections, it is a compelling demonstration of the value of specimen data from museums and 
other repositories for base-line ecological studies (Beck et al. 2012; Powney and Isaac 2015). At the same time, our dataset has some intrinsic limitations typical for information assembled from biological collections: incomplete sampling both in terms of sampling effort and geographic extent, compounded by the lack of taxonomic revisions for areas such as Argentina, which limited data mobilisation (Isaac and Pocock 2015). In our study, the latter resulted in a poor representation for the Neotropical Realm with regard to species richness and endemism despite our best efforts to overcome the taxonomic impediment imposed by lack of taxonomic revisions and other gaps in published knowledge. As is common for biological collections, information on sites where species were absent (i.e. true absences) was not available (Isaac and Pocock 2015). Because only locations where specimens were collected were used for the analysis, the relationships recovered by linear regressions reflect differences among sampled locations rather than between those locations and the overall habitat.

Although the analysis of relationships of bee species richness and environmental factors revealed ecologically meaningful associations, only a relatively low amount of variation (25-38.5\%) was explained by the selected environmental variables suggesting that unknown explanatory variables such as historical factors or biases in sampling, identification, and digitization may be at play. Although the scale of the analysis appeared to be appropriate as confirmed by the correlogram profile that can be interpreted as a linear gradient at macro-scales (Diniz-Filho et al. 2003), environmental factors acting on smaller scales than those accounted for in this study, such as inclination and aspect of slopes, soil type (known to be extremely important for ground-nesting bees, in particular edaphic specialists with respect to nesting like many Colletes), vegetation cover, land use, and availability and connectivity of microhabitats within the landscape (Westrich 1989; Murray et al. 2009; Rollin et al. 2015), might be relevant. We assume an invariant relationships among predictor and response variables throughout the entire span of the data; however the global coefficients from our models may be hiding local variation in relationships. To address this issue we carried out regression tree analysis, because it can capture non-stationary relationships (Hawkins 2012). Although the resulting tree models were generally consistent with the outputs of the GLM, they revealed complex relationships between species richness and other variables indicative of non-stationary effects (see Online Resource 3 for details).

The value of our study is that we present for the first time a global quantitative analysis of species richness and endemism patterns, as well as relationships between species richness and major environmental stress factors for a large group of solitary bees. With more than 500 described species, subfamily Colletinae has a nearly-global distribution, and includes species with a range of seasonality, soil preferences, flower specializations and distributions. Although the general patterns and relationships revealed by our research should be interpreted with a degree of caution due to the above limitations, they can nevertheless guide future regional biodiversity studies and identification of priority areas for conservation of bees together with their host plants.

Acknowledgements Databasing of Colletes bees from the AMNH, BBSL and additional collections was supported in part by NSF-DBI\#0956388, Collaborative Research: Collaborative Databasing of North American Bee Collections within a Global Informatics Network (PI John S. Ascher) with additional generous support to the AMNH from Mr. Robert G. Goelet, and at NUS from startup grants from DBS. Additional support to BBSL came from GBIF. We are grateful to Cory S. Sheffield, Royal Saskatchewan Museum, Regina, for making accessible Canadian Colletes records and Jens Mutke, Nees Institute for Biodiversity of Plants, University of Bonn, for providing a digital version of the global vascular plant 
diversity data. The manuscript was significantly improved by the insightful comments of Shawn Laffan, Bradford Hawkins and an anonymous reviewer.

Author contributions N.B. and M.K. conceived the ideas; M.K., T.G. and J.S.A. collected the data; N.B. analyzed the data; all authors contributed to the writing of the manuscript.

Open Access This article is distributed under the terms of the Creative Commons Attribution 4.0 International License (http://creativecommons.org/licenses/by/4.0/), which permits unrestricted use, distribution, and reproduction in any medium, provided you give appropriate credit to the original author(s) and the source, provide a link to the Creative Commons license, and indicate if changes were made.

\section{References}

Aizen MA, Garibaldi LA, Cunningham SA, Klein AM (2008) Long-term global trends in crop yield and production reveal no current pollination shortage but increasing pollinator dependency. Curr Biol 18:1572-1575. doi:10.1016/j.cub.2008.08.066

Allen AP, Brown JH, Gillooly JF (2002) Global biodiversity, biochemical kinetics, and the energeticequivalence rule. Science 297:1545-1548. doi:10.1126/science.1072380

Almeida EAB, Danforth BN (2009) Phylogeny of colletid bees (Hymenoptera: Colletidae) inferred from four nuclear genes. Mol Phylogenet Evol 50:290-309. doi:10.1016/j.ympev.2008.09.028

Ascher JS, Pickering J (2016) Discover Life bee species guide and world checklist (Hymenoptera: Apoidea: Anthophila). www.discoverlife.org/mp/20q?guide=Apoidea_species. Accessed 18 April 2016

Barthlott W, Hostert A, Kier G et al (2007) Geographic patterns of vascular plant diversity at continental to global scales. Erdkunde 61:305-315. doi:10.3112/erdkunde.2007.04.01

Barthlott W, Lauer W, Placke A (1996) Global distribution of species diversity in vascular plants: towards a world map of phytodiversity. Erdkunde 50:317-327. doi:10.3112/erdkunde.1996.04.03

Beck J, Ballesteros-Mejia L, Buchmann CM et al (2012) What's on the horizon for macroecology? Ecography (Cop) 35:673-683. doi:10.1111/j.1600-0587.2012.07364.x

Biesmeijer JC, Roberts SPM, Reemer M et al (2006) Parallel declines in pollinators and insect-pollinated plants in Britain and the Netherlands. Science 313:351-354. doi:10.1126/science.1127863

Blüthgen N, Klein AM (2011) Functional complementarity and specialisation: the role of biodiversity in plant-pollinator interactions. Basic Appl Ecol 12:282-291. doi:10.1016/j.baae.2010.11.001

Brittain C, Potts SG (2011) The potential impacts of insecticides on the life-history traits of bees and the consequences for pollination. Basic Appl Ecol 12:321-331. doi:10.1016/j.baae.2010.12.004

Cameron SA, Lozier JD, Strange JP et al (2011) Patterns of widespread decline in North American bumble bees. Proc Natl Acad Sci USA 108:662-667. doi:10.1073/pnas.1014743108

Crisp MD, Laffan S, Linder HP, Monro A (2001) Endemism in the Australian flora. J Biogeogr 28:183-198. doi:10.1046/j.1365-2699.2001.00524.x

De Palma A, Kuhlmann M, Roberts SPM et al (2015) Ecological traits affect the sensitivity of bees to landuse pressures in European agricultural landscapes. J Appl Ecol 52:1567-1577. doi:10.1111/1365-2664. 12524

Diniz-Filho JAF, Bini LM, Hawkins BA (2003) Spatial autocorrelation and red herrings in geographical ecology. Glob Ecol Biogeogr 12:53-64

Dixon AFG, Kindlmann P, Leps J, Holman J (1987) Why there are so few species of aphids, especially in the tropics. Am Nat 129:580-592. doi:10.1086/284659

Ferrari RR, Silveira FA (2015) The species of Colletinae (Hymenoptera: Colletidae) in the Brazilian state of Minas Gerais. Zootaxa 3914:245-274. doi:10.11646/zootaxa.3914.3.2

Fortel L, Henry M, Guilbaud L et al (2014) Decreasing abundance, increasing diversity and changing structure of the wild bee community (Hymenoptera: Anthophila) along an urbanization gradient. PLoS ONE. doi:10.1371/journal.pone. 0104679

Fragnière Y, Bétrisey S, Cardinaux L et al (2015) Fighting their last stand? A global analysis of the distribution and conservation status of gymnosperms. J Biogeogr 42:809-820. doi:10.1111/jbi.12480

Fründ J, Linsenmair KE, Blüthgen N (2010) Pollinator diversity and specialization in relation to flower diversity. Oikos 119:1581-1590. doi:10.1111/j.1600-0706.2010.18450.x

Gallai N, Salles J-M, Settele J, Vaissière BE (2009) Economic valuation of the vulnerability of world agriculture confronted with pollinator decline. Ecol Econ 68:810-821. doi:10.1016/j.ecolecon.2008.06. 014 
Garcillán PP, Ezcurra E, Riemann H (2003) Distribution and species richness of woody dryland legumes in Baja California, Mexico. J Veg Sci 14:475-486. doi:10.1111/j.1654-1103.2003.tb02174.x

Garibaldi LA, Aizen MA, Klein AM et al (2011a) Global growth and stability of agricultural yield decrease with pollinator dependence. Proc Natl Acad Sci USA 108:5909-5914. doi:10.1073/pnas.1012431108

Garibaldi LA, Steffan-Dewenter I, Kremen C et al (2011b) Stability of pollination services decreases with isolation from natural areas despite honey bee visits. Ecol Lett 14:1062-1072. doi:10.1111/j.14610248.2011.01669.x

Garibaldi LA, Steffan-Dewenter I, Winfree R et al (2013) Wild pollinators enhance fruit set of crops regardless of honey bee abundance. Science 339:1608-1611. doi:10.1126/science.1230200

Gaston KJ, Quinn RM, Blackburn TM, Eversham BC (1998) Species-range size distributions in Britain. Ecography (Cop) 21:361-370. doi:10.1111/j.1600-0587.1998.tb00401.x

Ghazoul J (2004) Alien abduction: disruption of native plant-pollinator interactions by invasive species. Biotropica 36:156-164. doi:10.1111/j.1744-7429.2004.tb00308.x

Goulson D, Nicholls E, Botías C, Rotheray EL (2015) Bee declines driven by combined stress from parasites, pesticides, and lack of flowers. Science 347:1432-1435. doi:10.1126/science.1255957

Grenyer R, Orme CDL, Jackson SF et al (2006) Global distribution and conservation of rare and threatened vertebrates. Nature 458:238. doi:10.1038/nature07834

Guerin GR, Ruokolainen L, Lowe AJ (2015) A georeferenced implementation of weighted endemism. Methods Ecol Evol 6:845-852. doi:10.1111/2041-210X.12361

Hawkins BA (2012) Eight (and a half) deadly sins of spatial analysis. J Biogeogr 39:1-9. doi:10.1111/j. 1365-2699.2011.02637.x

Hawkins BA, Porter EE (2003) Does herbivore diversity depend on plant diversity? The case of California butterflies. Am Nat 161:40-49. doi:10.1086/345479

Hegland SJ, Nielsen A, Lázaro A et al (2009) How does climate warming affect plant-pollinator interactions? Ecol Lett 12:184-195. doi:10.1111/j.1461-0248.2008.01269.x

Hijmans RJ, Cameron SE, Parra JL et al (2005) Very high resolution interpolated climate surfaces for global land areas. Int J Climatol 25:1965-1978. doi:10.1002/joc.1276

Hillebrand H (2004) On the generality of the latitudinal diversity gradient. Am Nat 163:192-211. doi:10. $1086 / 381004$

Holt BG, Lessard J-P, Borregaard MK et al (2013) An update of wallace's zoogeographic regions of the world. Science 339:74-78. doi:10.1126/science.1228282

Isaac NJB, Pocock MJO (2015) Bias and information in biological records. Biol J Linn Soc 115:522-531. doi:10.1111/bij.12532

Kehoe L, Kuemmerle T, Meyer C et al (2015) Global patterns of agricultural land-use intensity and vertebrate diversity. Divers Distrib 21:1308-1318. doi:10.1111/ddi.12359

Kerr JT (1997) Species richness, endemism, and the choice of areas for conservation. Conserv Biol 11:1094-1100. doi:10.1046/j.1523-1739.1997.96089.x

Kleidon A, Mooney HA (2000) A global distribution of biodiversity inferred from climatic constraints: results from a process-based modelling study. Glob Change Biol 6:507-523. doi:10.1046/j.1365-2486. 2000.00332.x

Klein A-M, Vaissière BE, Cane JH et al (2007) Importance of pollinators in changing landscapes for world crops. Proc Biol Sci 274:303-313. doi:10.1098/rspb.2006.3721

Kriticos DJ, Webber BL, Leriche A, et al (2012) CliMond: global high-resolution historical and future scenario climate surfaces for bioclimatic modelling. Methods Ecol Evol 3:53-64. doi:10.1111/j.2041210X.2011.00134.x

Kouki J, Niemela P, Viitasaari M (1994) Reversed latitudinal gradient in species richness of sawflies (Hymenoptera, Symphyta). Ann Zool Fenn 31:83-88

Kuhlmann M (2002) Neue Arten der Bienengattung Colletes Latr. aus Südtibet mit Beschreibung der Route der „, Deutschen Tibet Expedition Ernst Schäfer 1938/39“(Hymenoptera: Apidae: Colletinae). Linzer Biol Beitr 34:1155-1178

Kuhlmann M (2005) Faunistik und Zoogeographie der Bienengattung Colletes Latreille 1802 (Hymenoptera: Apidae: Colletinae) in Mittelasien. Linzer Biol Beitr 37:1353-1396

Kuhlmann M (2009) Patterns of diversity, endemism and distribution of bees (Insecta: Hymenoptera: Anthophila) in southern Africa. S Afr J Bot 75:726-738. doi:10.1016/j.sajb.2009.06.016

Kuhlmann M, Guo D, Veldtman R, Donaldson J (2012) Consequences of warming up a hotspot: species range shifts within a centre of bee diversity. Divers Distrib 18:885-897. doi:10.1111/j.1472-4642.2011. 00877.x

Kuhlmann M, Proshchalykin MY (2014) The bees of the genus Colletes Latreille 1802 of the European part of Russia, with keys to species (Hymenoptera: Apoidea: Colletidae). Zootaxa 3878:201-247. doi:10. 11646/zootaxa.3878.3.1 
Laffan SW, Crisp MD (2003) Assessing endemism at multiple spatial scales, with an example from the Australian vascular flora. J Biogeogr 30:511-520. doi:10.1046/j.1365-2699.2003.00875.x

Laffan SW, Ramp D, Roger E (2013) Using endemism to assess representation of protected areas-the family Myrtaceae in the Greater Blue Mountains World Heritage Area. J Biogeogr 40:570-578. doi:10. 1111/jbi.12001

Laity T, Laffan SW, González-Orozco CE et al (2015) Phylodiversity to inform conservation policy: an Australian example. Sci Total Environ 534:131-143. doi:10.1016/j.scitotenv.2015.04.113

Landeiro VL, Magnusson WE (2011) The geometry of spatial analyses: implications for conservation biologists. Braz J Nat Conserv 9:7-20. doi:10.4322/natcon.2011.002

Legendre P (1993) Spatial autocorrelation: trouble or new paradigm? Ecology 74:1659-1673

Legendre P, Legendre L (1998) Numerical ecology. Elsevier, Amsterdam

Leonhardt SD, Gallai N, Garibaldi LA et al (2013) Economic gain, stability of pollination and bee diversity decrease from southern to northern Europe. Basic Appl Ecol 14:461-471. doi:10.1016/j.baae.2013.06. 003

Lesslie RG, Taylor D, Maslen M (1995) National wilderness inventory: handbook of principles, procedures and usage, 2nd edn. Australian Heritage Commission, Canberra

Lewinsohn TM, Roslin T (2008) Four ways towards tropical herbivore megadiversity. Ecol Lett 11:398-416. doi:10.1111/j.1461-0248.2008.01155.x

Lobo JM, Lumaret JP, Jay-Robert P (2002) Modelling the species richness distribution of French dung beetles (Coleoptera, Scarabaeidae) and delimiting the predictive capacity of different groups of explanatory variables. Glob Ecol Biogeogr 11:265-277. doi:10.1046/j.1466-822X.2002.00291.x

Lumley T, Diehr P, Emerson S, Chen L (2002) The importance of the normality assumption in large public health data sets. Annu Rev Public Health 23:151-169. doi:10.1146/annurev.publheath.23.100901. 140546

Memmott J, Craze PG, Waser NM, Price MV (2007) Global warming and the disruption of plant-pollinator interactions. Ecol Lett 10:710-717. doi:10.1111/j.1461-0248.2007.01061.x

Michener CD (2007) The bees of the world, 2nd edn. Johns Hopkins Press, Baltimore

Michener CD (1979) Biogeography of the bees. Ann MO Bot Gard 66:277-347. doi:10.3417/2007065

Mittelbach GG, Schemske DW, Cornell HV et al (2007) Evolution and the latitudinal diversity gradient: speciation, extinction and biogeography. Ecol Lett 10:315-331. doi:10.1111/j.1461-0248.2007.01020. $\mathrm{X}$

Moldenke AR (1976) Evolutionary history and diversity of the bee faunas of Chile and Pacific North America. Wasmann J Biol 34:147-178

Müller A, Kuhlmann M (2008) Pollen hosts of western palaearctic bees of the genus Colletes (Hymenoptera: Colletidae): the Asteraceae paradox. Biol J Linn Soc 95:719-733. doi:10.1111/j.1095-8312.2008. 01113.x

Murray TE, Kuhlmann M, Potts SG (2009) Conservation ecology of bees: populations, species and communities. Apidologie 40:211-236. doi:10.1051/apido/2009015

Myers N, Mittermeier RA, Mittermeier CG et al (2000) Biodiversity hotspots for conservation priorities. Nature 403:853-858. doi:10.1038/35002501

Nelder JA, Wedderburn RWM (1972) Generalized linear models. J R Stat Soc Ser A 135:370-384. doi:10. $2307 / 2344614$

Nieto A, Roberts SPM, Kemp J et al (2014) European red list of bees. Publication Office of the European Union, Luxembourg

Niu Z-Q, Zhu C-D, Kuhlmann M (2013) Bees of the Colletes clypearis-group (Hymenoptera: Apoidea: Colletidae) from China with descriptions of seven new species. Zootaxa 3745:101-151. doi:10.11646/ zootaxa.3780.3.5

Niu Z-Q, Zhu C-D, Kuhlmann M (2014) The bees of the genus Colletes (Hymenoptera: Apoidea: Colletidae) from China. Zootaxa 3856:451-483

Noskiewicz J (1936) Die paläarktischen Colletes-Arten. Prace Naukowe Wydaw Tow Naukowego we Lwowie 3:1-531

Ollerton J, Erenler H, Edwards M, Crockett R (2014) Extinctions of aculeate pollinators in Britain and the role of large-scale agricultural changes. Science 346:1360-1362. doi:10.1126/science.1257259

Ollerton J, Winfree R, Tarrant S (2011) How many flowering plants are pollinated by animals? Oikos 120:321-326. doi:10.1111/j.1600-0706.2010.18644.x

Olson DM, Dinerstein E (2002) The global 200: priority ecoregions for global conservation. Ann MO Bot Gard 89:199-224. doi:10.2307/3298564

Patiny S, Michez D (2007) Biogeography of bees (Hymenoptera, Apoidea) in Sahara and the Arabian deserts. Insect Syst Evol 38:19-34. doi:10.1163/187631207788784012 
Patiny S, Michez D, Kuhlmann M et al (2009a) Factors limiting the species richness of bees in Saharan Africa. Bull Entomol Res 99:337-346. doi:10.1017/S0007485308006433

Patiny S, Rasmont P, Michez D (2009b) A survey and review of the status of wild bees in the WestPalaearctic region. Apidiologie 40:313-331. doi:10.1051/apido/2009028

Potts SG, Biesmeijer JC, Kremen C et al (2010) Global pollinator declines: trends, impacts and drivers. Trends Ecol Evol 25:345-353. doi:10.1016/j.tree.2010.01.007

Powney GD, Isaac NJB (2015) Beyond maps: a review of the applications of biological records. Biol J Linn Soc 115:532-542. doi:10.1111/bij.12517

Pradervand J-N, Pellissier L, Randin CF, Guisan A (2014) Functional homogenization of bumblebee communities in alpine landscapes under projected climate change. Clim Change Responses 1:1. doi:10. 1186/s40665-014-0001-5

Quintero C, Morales CL, Aizen MA (2009) Effects of anthropogenic habitat disturbance on local pollinator diversity and species turnover across a precipitation gradient. Biodivers Conserv 19:257-274. doi:10. 1007/s10531-009-9720-5

Rangel TFLVB, Diniz-Filho JAF, Bini LM (2010) SAM: a comprehensive application for spatial analysis in macroecology. Ecography 33:46-50. doi:10.1111/j.1600-0587.2009.06299.x

Roberts S, Potts S, Biesmeijer K et al (2011) Assessing continental-scale risks for generalist and specialist pollinating bee species under climate change. BioRisk 6:1-18. doi:10.3897/biorisk.6.1325

Rollin O, Bretagnolle V, Fortel L et al (2015) Habitat, spatial and temporal drivers of diversity patterns in a wild bee assemblage. Biodivers Conserv 24:1195-1214. doi:10.1007/s10531-014-0852-X

Scheper J, Reemer M, van Kats R et al (2014) Museum specimens reveal loss of pollen host plants as key factor driving wild bee decline in the Netherlands. Proc Natl Acad Sci USA 111:17552-17557. doi:10. 1073/pnas.1412973111

Schuldt A, Wang Z, Zhou H, Assmann T (2009) Integrating highly diverse invertebrates into broad-scale analyses of cross-taxon congruence across the Palaearctic. Ecography (Cop) 32:1019-1030. doi:10. 1111/j.1600-0587.2009.05973.x

Scriven JJ, Woodall LC, Tinsley MC et al (2015) Revealing the hidden niches of cryptic bumblebees in Great Britain: implications for conservation. Biol Conserv 182:126-133. doi:10.1016/j.biocon.2014. 11.027

Stephen WP (1954) A revision of the bee genus Colletes in America north of Mexico. Univ Kansas Sci Bull 36:149-527

Tylianakis JM (2013) The global plight of pollinators. Science 339:1532-1533. doi:10.1126/science. 1235464

UNEP-WCMC (2013) Centres of plant diversity. Version 1.0 (digital reproduction of centres of plant diversity. In: Davis SD, Heywood VH, Hamilton AC (eds) WWF and IUCN, Gland

Vázquez-Rivera H, Currie DJ (2015) Contemporaneous climate directly controls broad-scale patterns of woody plant diversity: a test by a natural experiment over 14,000 years. Glob Ecol Biogeogr 24:97-106. doi:10.1111/geb.12232

Ver Hoef JM, Boveng PL (2007) Quasi-poisson versus negative binomial regression: how should we model overdispersed count data? Ecology 88:2766-2772. doi:10.1890/07-0043.1

Westrich P (1989) Die Wildbienen Baden-Württembergs. Eugen Ulmer, Stuttgart

Williams PH (2000) Some properties of rarity scores used in site quality assessment. Br J Entomol Nat Hist $13: 73-86$

Williams PH, Colla S, Xie Z (2009) Bumblebee vulnerability: common correlates of winners and losers across three continents. Conserv Biol 23:931-940. doi:10.1111/j.1523-1739.2009.01176.x

Williams PH (1998) An annotated checklist of bumble bees with an analysis of patterns of description (Hymenoptera: Apidae, Bombini). Bull Nat Hist Mus Entomol Ser 67:79-152

Williams PH (1986) Environmental change and the distributions of British bumble bees (Bombus Latr.). Bee World 67:50-61. doi:10.1080/0005772X.1986.11098871

Williams PH (1989) Why are there so many species of bumble bees at Dungeness? Bot J Linn Soc 101:31-44. doi:10.1111/j.1095-8339.1989.tb00134.x

Williams PH, Bystriakova N, Huang J et al (2015) Bumblebees, climate and glaciers across the Tibetan plateau (Apidae: Bombus Latreille). Syst Biodivers 13:164-181. doi:10.1080/14772000.2014.982228

Williams PH, Thorp RW, Richardson L, Colla S (2014) mblebees of North America. Princeton University Press, Princeton and Oxford

Zeileis A, Kleiber C, Jackman S (2008) Regression models for count data in R. J Stat Softw 27:1-25. doi:10. 18637/jss.v027.i08

Zurbuchen A, Müller A (2012) Wildbienenschutz-von der Wissenschaft zur Praxis. Bristol-Stiftung, Haupt Verlag, Zürich, Bern 